\title{
Estimasi Laju Timbulan Sampah dan Kebutuhan Landfill Periode 2018-2027 (Studi Kasus Kec. Mentawa Baru Ketapang, Kab. Kotawaringin Timur, Kalimantan Tengah)
}

\author{
Rudy Yoga Lesmana \\ Program Studi Teknik Lingkungan Universitas Muhammadiyah Palangkaraya \\ email: yoga.lesmana@umpalangkaraya.ac.id
}

\begin{abstract}
ABSTRAK. Pengelolaan sampah domestik merupakan salah satu tantangan penting dalam upaya mewujudkan lingkungan bebas sampah di Kec. Mentawa Baru Ketapang. Penelitian ini bertujuan untuk mengidentifikasi jumlah laju timbulan sampah pada tahun proyeksi 2018-2027 dan menentukan kebutuhan volume untuk menampung sampah pada landfill / Tempat Pemrosesan Akhir (TPA) Sampah pada tahun perencanaan. Penelitian ini termasuk dalam penelitian desktiftif kualitatif yang bertujuan untuk mendeskripsikan kondisi laju timbulan sampah di Kecamatan MB Ketapang pada tahun proyeksi. Timbulan sampah per kapita di Kecamatan Mentawa Baru Ketapang yaitu sebesar 0,23 kg/org/hari. Total jumlah timbulan sampah pada tahun proyeksi 2018-2027 yaitu 149.841 ton dan kebutuhan landfill yaitu yaitu $299.682 \mathrm{~m}^{3}$.
\end{abstract}

Kata kunci : Sampah, timbulan sampah, landfill

\section{PENDAHULUAN}

Permasalahan limbah padat atau yang sering disebut dengan sampah, selama ini terus meningkat di Indonesia yang menyebabkan buruknya kondisi pengelolaan lingkungan di Indonesia, dan ditambah lagi dengan minimnya fasilitas pengelolaan sampah di Indonesia menyebabkan permasalahan ini menjadi sangat kompleks untuk dihadapi, selain itu Urbanisasi yang cepat dan pertumbuhan yang cepat dalam standar kehidupan di kota-kota, menjadi alasan utama dalam peningkatan jumlah dan kompleksitas sumber limbah (Kashid et al., 2015). Gerakan yang saat inisedang marak digadang gadang sebagai gerakan hari bebas sampah pada tahun 2020 dapat menjadi sangat mustahil untuk diterapkan, jika kita melihat kondisi lingkungan kita saat ini.

Sampah padat perkotaan atau yang biasa disebut dengan Municipal Solid waste (MSW) adalah istilah yang biasanya diterapkan pada kumpulan limbah heterogen yang diproduksi di daerah perkotaan. Pada umumnya, limbah perkotaan dapat dibagi menjadi dua komponen utama: organik dan anorganik. Karakteristik dan kuantitas limbah padat yang dihasilkan di suatu wilayah merupakan fungsi standar kehidupan di kota atau negara (Sudibyo et al., 2017). Limbah padat atau Sampah menurut Tchobanouglous et al (1993) merupakan bahan buangan yang berbentuk padat maupun semi padat yang berasal dari aktifitas manusia maupun hewan yang dibuang karena tidak memiliki manfaat bagi pemiliknya. Banyak limbah padat perkotaan yang dihasilkan hanya masuk ke Tempat Pembungan Sampah dan setelah itu dibiarkan begitu saja hingga menumpuk. Tekhnologi pengelolaan sampahpun masih dengan pola tradisional yaitu dengan cara diangkut, ditumpuk dan di bakar, dan metode yang umum digunakan dalam pembunagan akhir sampah yaitu metode open dumping. 
Oraon, et al 2016, berpendapat bahwa metode Open dumping adalah metode padat yang paling umum digunakan pada pembuangan limbah padat di banyak negara berkembang termasuk daerah perkotaan. Pemilihan lokasi TPA yang sesuai sangat penting untuk meminimalkan dampak negatif dari metode ini. Ketersediaan lahan untuk tempat pembuangan akhir sampah, harus sudah dapat di estimasi sedini mungkin, agar nantinya tidak terjadi penumpukan sampah dimana-mana akibat kurangnya ketersediaan lahan untuk pembuangan sampah. Pengelolaan limbah padat sangat penting dalam melindungi lingkungan dan memastikan kesehatan manusia, oleh karena itu diperlukan strategi baru dalam mengatasi limbah tersebut (Abbas et al., 2017).

Berdasarkan permasalahan tersebut maka Penelitian ini bertujuan untuk, mengestimasi jumlah laju volume sampah atau limbah domestik yang dihasilkan pada tahun proyeksi 2018-2027 di Kecamatan Mentawa Baru Ketapang, Kabupaten Kotawaringin Timur, Kalimantan Tengah dan selanjutnya untuk menentukan kebutuhan volume lahan untuk menampung sampah pada landfill/ Tempat Pemrosesan Akhir (TPA) Sampah pada tahun perencanaan.

\section{METODE PENELITIAN}

\section{Lokasi dan waktu Penelitian}

Penelitian dilakukan di Kecamatan

Mentawa Baru Ketapang, atau masuk kedalam wilayah administratfi Kabupaten Kotawaringin Timur. Daerah ini memmpunyai luas wilayah sebesar $726 \mathrm{~km}^{2}$ yang terdiri dari 6 Desa dan 5 Kelurahan, untuk lebih jelasnya dapat dilihat dari gambar 1. (Badan Pusat Statistik Kab. Kotawaringin Timur, 2016)

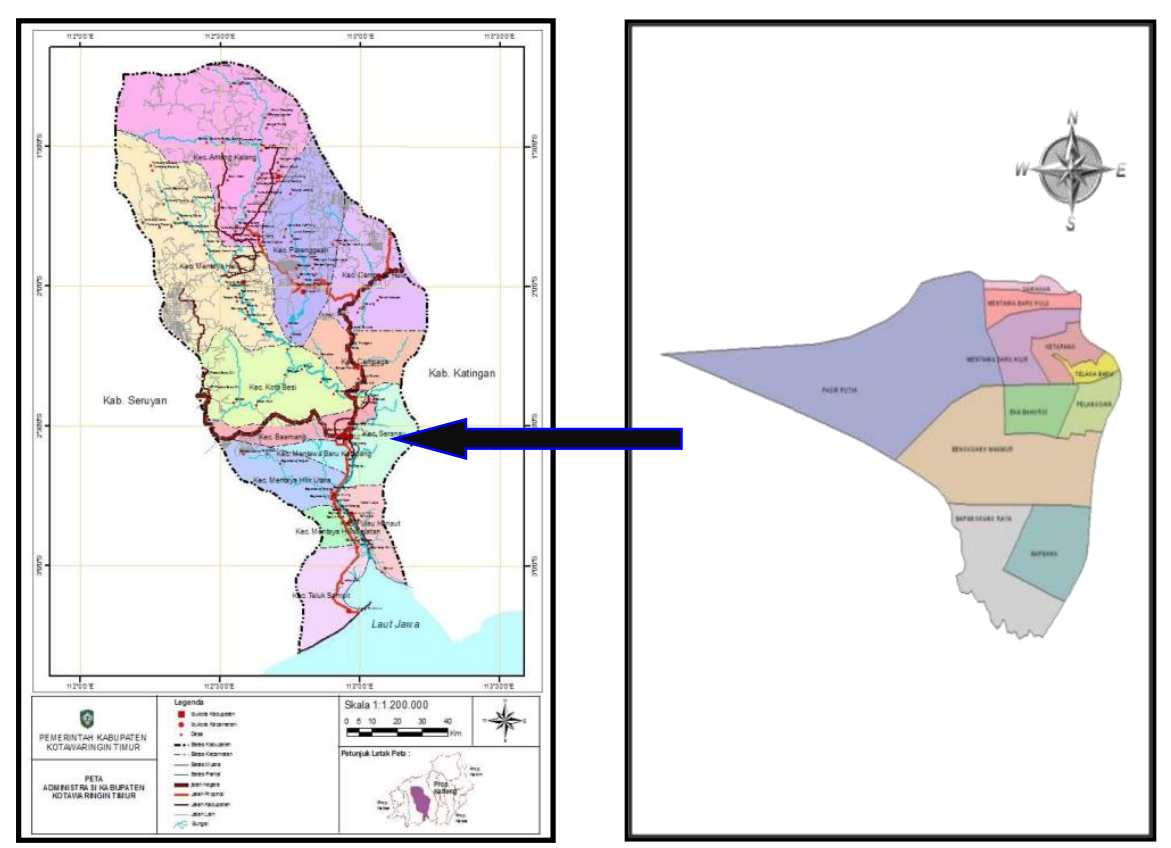

Gambar 1. Peta Wilayah Kecamatan Mentawa Baru Ketapang (Ditujukan Pada Panah Hitam) Sumber: Badan Pusat Statistik, Kab. Kotawaringin Timur 2016

\section{Jenis Penelitian}

Penelitian ini termasuk penelitian deskriftif kualitatif, yang bertujuan untuk mendeskripsikan kondisi laju timbulan sampah dan juga estimasi kebutuhan volume untuk menampung sampah pada Landfill/Tempat Pemrosesan Akhir (TPA) sampah di Kecamatan Mentawa Baru
Ketapang, Kabupaten Kotawaringin Timur pada tahun proyeksi 2018-2027.

\section{Batasan Penelitian}

Penelitiaan ini hanya dilakukan sebatas mengestimasi jumlah timbulan sampah dan mengestimasi kebutuhan volume lahan untuk menangani timbulan sampah pada Tempat 
Pemrosesan Akhir (TPA) sampah pada tahun proyeksi 2018-2027 di Kecamatan Mentawa Baru Ketapang saja, dan tidak mengestimasi timbulan sampah yang berasal dari kecamatan yang posisinya berbatasan langsung dengan Kecamatan Mentawa Baru Ketapang.

\section{HASIL DAN PEMBAHASAN}

\section{Estimasi Jumlah Penduduk Pada Tahun Proyeksi}

Estimasi jumlah penduduk di wilayah Kecamatan Mentawa Baru Ketapang pada tahun proyeksi (2018-2027) dapat dihitung berdasarkan perhitungan proyeksi penduduk metode Geometrik, atau seperti pada rumus berikut:

$$
\mathrm{P}_{\mathrm{i}}=\mathrm{P}_{\mathrm{o}}(1+\mathrm{r})^{\mathrm{n}}
$$

$\mathrm{P}_{\mathrm{n}} \quad=$ penduduk pada tahun $\mathrm{n}$

$\mathrm{P}_{\mathrm{O}} \quad=$ penduduk pada tahun awal

$1=$ angka konstanta

$\mathrm{r} \quad=$ angka pertumbuhan penduduk (dalam persen)

$\mathrm{n} \quad=$ jumlah rentang tahun dari awal hingga tahun $\mathrm{n}$

Berdasarkan penggunaan rumus proyeksi penduduk metode Geometrik, tingkat persentase pertumbuhan penduduk di Kecamatan Mentawa Baru Ketapang pada tahun awal 2016 yaitu sebesar 1,53 \% dan proyeksi pada tahun perencanaan yaitu sebesar $1,22 \%$. Untuk Lebih Lanjutnya dapat dilihat pada tabel 1 .

Tabel 1Pertumbuhan Penduduk di Kecamatan MB Ketapang Pada Tahun Proyeksi 2018-2027

\begin{tabular}{cccc}
\hline No & $\begin{array}{c}\text { Tahun } \\
\text { Ke-n }\end{array}$ & $\begin{array}{c}\text { Jumlah } \\
\text { Penduduk }\end{array}$ & $\begin{array}{c}\text { Pertumbuhan } \\
\text { Penduduk } \\
(\%)\end{array}$ \\
\hline 3 & 2016 & 85623 & $1,53 \%$ \\
4 & 2017 & 86664 & $1,22 \%$ \\
5 & 2018 & 87718 & $1,22 \%$ \\
6 & 2019 & 88784 & $1,22 \%$ \\
7 & 2020 & 89864 & $1,22 \%$ \\
8 & 2021 & 90956 & $1,22 \%$ \\
9 & 2022 & 92062 & $1,22 \%$ \\
10 & 2023 & 93181 & $1,22 \%$ \\
11 & 2024 & 94314 & $1,22 \%$ \\
12 & 2025 & 95461 & $1,22 \%$ \\
13 & 2026 & 96621 & $1,22 \%$ \\
14 & 2027 & 97796 & $1,22 \%$ \\
\hline
\end{tabular}

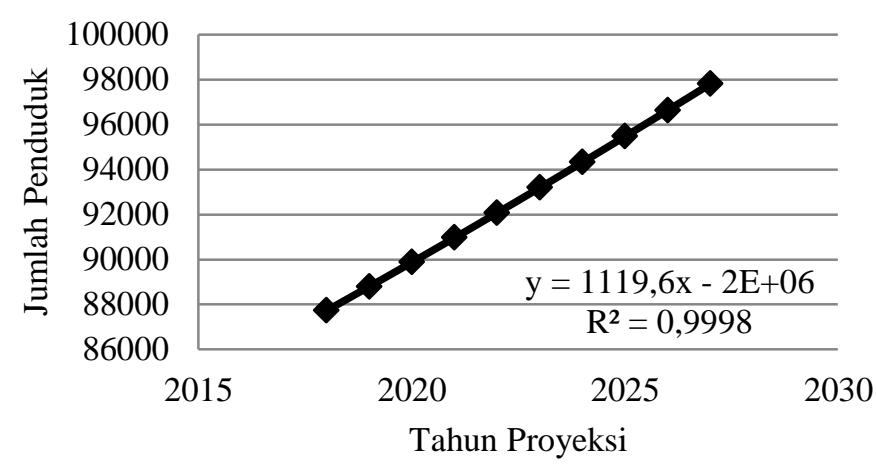

Gambar 2. Proyeksi Jumlah penduduk pada tahun 2018-2027

Pada tabel 1 dan gambar 2 tersebut dijelaskan proyeksi jumlah penduduk pada rentang waktu 2018-2027, yang diproyeksikan akan menjadi sumber penghasil sampah, mengingat semakin bertambahnya jumlah penduduk maka jumlah volume sampah yang dihasilkan akan semakin besar pula.

\section{Perhitungan Jumlah Sampah Domestik Untuk Periode Tahun 2018-2027}

Berdasarkan estimasi jumlah penduduk dari perhitungan sebelumnya kita dapat menggunakan asumsi bahwa timbulan sampah yang dihasilkan per orang per hari adalah 0,23 kg/org/hari (Al-anbari et al., 2016) dan untuk jumlah sampah yang akan dihasilkan pada tahun proyeksi tersebut

Tabel 2. Banyaknya Sampah Yang Dihasilkan Di Kecamatan Mentawa Baru Ketapang Dan Populasinya

\begin{tabular}{|c|c|c|c|c|c|}
\hline Tahun & Populasi & $\begin{array}{c}\text { Jumlah } \\
\text { hari }\end{array}$ & $\begin{array}{c}\mathrm{kg} / \text { org } \\
\text { /hari }\end{array}$ & $\begin{array}{c}\text { Sampah } \\
\mathrm{kg} / \text { tahun }\end{array}$ & $\begin{array}{c}\text { Sampah } \\
\text { Ton/Tahun }\end{array}$ \\
\hline 2017 & *86664 & 360 & 0.23 & 7175779 & 7176 \\
\hline 2018 & 87717 & 360 & 0.23 & 7262968 & 7263 \\
\hline 2019 & 88784 & 360 & 0.23 & 7351315 & 7351 \\
\hline 2020 & 89863 & 360 & 0.23 & 7440656 & 7441 \\
\hline 2021 & 90956 & 360 & 0.23 & 7531157 & 7531 \\
\hline 2022 & 92061 & 360 & 0.23 & 7622651 & 7623 \\
\hline 2023 & 93181 & 360 & 0.23 & 7715387 & 7715 \\
\hline 2024 & 94314 & 360 & 0.23 & 7809199 & 7809 \\
\hline 2025 & 95460 & 360 & 0.23 & 7904088 & 7904 \\
\hline 2026 & 96621 & 360 & 0.23 & 8000219 & 8000 \\
\hline 2027 & 97796 & 360 & 0.23 & 8097509 & 8098 \\
\hline \multicolumn{4}{|c|}{ Jumlah } & 83910928 & 83911 \\
\hline
\end{tabular}




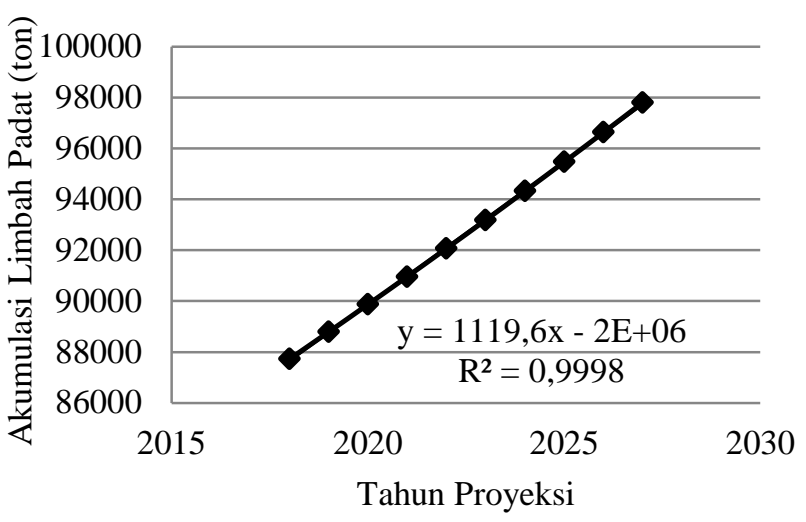

Gambar 2. Proyeksi Jumlah penduduk pada tahun 2018-2027

Dari tabel 2 dan gambar 2 dapat dilihat bahwa pada saat terjari peningkatan populasi jumlah penduduk setiap tahunnya, selalu diimbangi dengan meningkatnya jumlah volume sampah yang dihasilkan. Perhitungan pada tabel 2 di dasarkan atas jumlah timbulan sampah yang dihasilkan setiap orang/hari selama 360 hari atau per tahun. Jumlah timbulan sampah yang dihasilkan sangat ditentukan oleh seluruh aktifitas masyarakat di kota tersebut. Untuk timbulan sampah, menurut Darmasetiawan, 2004, umumnya dipakai ukuran volume $\left(\mathrm{m}^{3} / \mathrm{hari}\right)$ atau berat (ton/hari) dengan asumsi yang digunakan menurut Al-Anbari et al, 2016 bahwa laju timbulan sampah yang dihasilkan tiap orang perhari rata-rata yaitu sekitar $0,23 \mathrm{~kg}$, sehingga sampah yang dihasilkan dalam rentang waktu 10 tahun yaitu sekitar $83.910 .929 \mathrm{~kg}$ atau 83.911 ton untuk Kecamatan Mentawa Baru Ketapang tersebut.

\section{Volume Timbulan Sampah Di Tempat Pemrosesan Akhir (TPA) Sampah}

Sampah yang diproyeksikan terkumpul ke TPA dalam rentang waktu tahun 20182027 selanjutnya akan dilakukan pemadatan, sehinggga beratnya menjadi $149.841 \mathrm{~m}^{3}$ hal itu dikarenakan terjadinya penyusutan berat jenis sampah, untuk lebih jelasnya dapat dilihat pada tabel 3 .
Tabel 3. Akumulasi Masa Dan Volume Sampah Di Wilayah Kecamatan Mentawa Baru Ketapang

\begin{tabular}{cccc}
\hline No & $\begin{array}{c}\text { Wilayah } \\
\text { Studi }\end{array}$ & $\begin{array}{c}\text { Akumulasi } \\
\text { sampah dari tahun } \\
2018-2028(\text { ton })\end{array}$ & $\begin{array}{c}\text { Volume } \\
\text { timbulan } \\
\left(\mathrm{m}^{3}\right)^{* *}\end{array}$ \\
\hline Mentawa \\
Baru \\
ketapang
\end{tabular}

Tabel 4. Akumulasi Dan Pemadatan Volume Sampah Untuk Persayaratan Pembuangan Di Tpa

\begin{tabular}{ccc}
\hline No & Parameter & Wilayah Studi \\
\hline 1 & Akumulasi Volume $\left(\mathrm{m}^{3}\right)$ & 149.841 \\
2 & $+12 \%$ Cover & $17.980,92$ \\
3 & Total Volume $\left(\mathrm{m}^{3}\right)$ & $167.821,92$ \\
4 & Kedalaman area 2 dan 3 m & $55.940,64$ \\
\hline
\end{tabular}

Pada tabel 4 menjelaskan akumulasi sampah yang terdapat pada TPA sebesar $149.841 \mathrm{~m}^{3}$ dan menurut Al-anbari et al., 2016 bahwa untuk dapat meminimalkan bahaya lingkungan yang akan terjadi maka volume sampah harian di TPA harus di tutup dengan menggunakan tanah yang dipadatkan sebesar $10-15 \%$ dari jumlah volume sampah yang dihasilkan setiap hari jika metode TPA yang digunakan adalah Sanitary landfill, sedangkan pada metode open dumping tidak bisa digunakan karena sampah hanya ditumpuk saja.

\section{KESIMPULAN}

Berdasarkan penelitian yang telah dilakukan, maka penulis mendapatkan kesimpulan:

1. Jumlah timbulan sampah per org/hari yaitu rata-rata $0,23 \mathrm{~kg} / \mathrm{org} /$ hari

2. Total jumlah timbulan sampah pada tahun proyeksi 2018-2027 yaitu 149.841 ton dan kebutuhan landfill yaitu yaitu $299.682 \mathrm{~m}^{3}$

3. Tanah penutup lapisan sampah yang akan dipadatkan di TPA pada permukaan sampah berkisar antara 10$15 \%$ dari ketebalan timbunan sampah tersebut

4. Metode penutupan timbunan sampah dapat dilakukan pada sistem pengelolaan Open Dumping 


\section{DAFTAR PUSTAKA}

Abbas, I.I., Chaaban, J.K. \& Shaar, A.A., 2017, Solid Waste Management in Lebanon: Challenges Solid Waste Management in Lebanon: Challenges and Recommendations. (October).

Al-anbari, M.A., Thameer, M.Y., Al-ansari, N. \& Knutsson, S., 2016, Estimation of Domestic Solid Waste Amount and Its Required Landfill Volume in Najaf Governorate, Iraq for the Period 20152035. i(June): 339-346.

Darmaseiawan, M., 2004, Sampah dan Sistem Pengelolaannya, Ekamitra Engineering Jakarta.

Kashid, S.D., Nagne, A.D. \& Kale, K. V., 2015, Solid Waste Management: Bin Allocation and Relocation By Using Remote Sensing \& Geographic Information System. 143-148.
Oraon, A. saxena and R., 2016, Municipal solid waste management in Bareilly. International journal of technical research and applications, 4(3): 51-56.

Sudibyo, H., Majid, A.I., Pradana, Y.S., Budhijanto, W., Deendarlianto \& Budiman, A., 2017, Technological Evaluation of Municipal Solid Waste Management System in Indonesia. Energy Procedia, 105(May): 263-269. Tersedia di http://dx.doi.org/10.1016/j.egypro.2017. 03.312 .

Tchobanouglous, George, Theisen, Hilary, Virgil, 1993, Integrated Solid Waste Management, Mc Graw-Hill, Singapore.

Badan Pusat Statistik, Kecamatan Kotawaringin Timur dalam Angka 2016. 